\title{
About János Esterházy in the context of a Central European dialogue Conference and round table discussion in Esterházy's homeland
}

\author{
Nitra, Slovakia, 5 March 2014
}

On 5 March 2014, the Faculty of Central European Studies of Konštantín the Philosopher University in Nitra, Slovakia, hosted an international scientific conference and round table discussion on one of the most significant representatives of the Hungarian minority of First Republic Czechoslovakia of 1930s, Count János Esterházy.

Let's shortly remind ourselves that on 14 December 1932, János Esterházy was elected President of the Land Christian-socialist Party (Országos Keresztény Socialista Párt; OKSzP), one of the two central and parliamentary political parties of the Hungarian minority of the First Czechoslovak Republic, along with the Hungarian National party (Magyar Nemzeti Párt). Esterházy as president continued the opposition political line of the party, which he considered the only correct line. János Esterházy was an autonomist politician, and one of his basic political goals consisted in achieving the autonomous status of Slovakia within the Czechoslovak state, as he considered it the only guarantee for a consequent provision of rights not only for the Slovak Hungarians and Germans but also for the Slovaks who, at that time, constituted one of the two branches of the artificially created Czechoslovak nation, in order to ensure at least a two-third share of the state-forming nation in the national composition of the Czechoslovak state. ${ }^{1}$ In connection with the autonomist orientation of the party, Esterházy asked simultaneously for practical implementation of the autonomy of Carpathian Ruthenia to which Prague was obliged by its international legal commitments. It must be remembered that both central political subjects of the Hungarian minority of Czechoslovakia of that time were considered so-called negativistic parties, as both of them refused the constitutional limits of the Czechoslovak state, asking for consequent decen-

1 The first census performed in the Czechoslovak Republic in 1921 showed that 8,760,937 claimed allegiance to Czechoslovak nationality. The total number of inhabitants amounted to 13,374,364, which means that the percentage of Czechoslovaks amounted only to $65,5 \%$ of total population. Although the census included the Slovaks in the category of Czechoslovak nationality, more detailed statistics inform also about the number of Slovaks in Slovakia and Carpathian Ruthenia who amounted to 1,952,368, i.e. 14,6\% of the total population of the state in 1921. The above stated figures show that the percentage of Czechs in the total population of the Czechoslovak state amounted only to 50,9\%, i.e. actually to only one half of all population. Compare Československá statistika, Svazek 9, Řada 6, Sčítání lidu, Sešit 1, Sčítání lidu v Republice Československé from 15 February 1921, Part I (hereinafter referred to only as ČSS - Sčítání lidu 1921), Praha 1924, Tab. 50, Národnost československých státních př́slušníků. I., p. 60* and Tab. 71. Národnost na Slovensku a v Podkarpatské Rusi roku 1910 a 1921, p. 75*. 
tralization of the state, or autonomous rearrangement of the republic, respectively, in order to provide the individual national minorities with maximal autonomous competences.

Within a few years, János Esterházy became a leading political personality of the Hungarian minority in Czechoslovakia. After the fourth and at the same time last parliamentary election of the First Czechoslovak Republic, held in May 1935, he was elected also deputy of the National Assembly. Esterházy as leading political representative of a Hungarian minority, since June 1936 as executive president of the United Hungarian Party (Egyesült Magyar Párt) created by a merger of both above stated opposition political subjects of the Hungarian minority, also negotiated several times with leading political representatives of the First Czechoslovac Republic in the politically dramatic years of the second half of the 1930s. In December 1935, in spite of his opposition political line, he enforced, together with former president of OKSzP Géza Szüllo", the election of long-time Foreign Minister, Edvard Beneš, to the second Czechoslovak president after the resigned Tomáš Garrigue Masaryk among the legislators of both political parties of the Hungarian minority in the two-chamber National Assembly. All that in spite of the fact that Beneš, together with Masaryk, was criticized by the Hungarians as having direct responsibility for the manner of creation of the new state, or for the separation of a large Hungarian minority from the newly created Czechoslovak state without asking in a plebiscite, or for the form of the constitutional limits of the state that were adopted in the absence of representatives of national minorities at negotiations about the future form of Czechoslovakia, respectively. It was the first time that legislators of both political formations of the Hungarian minority did not take a negativistic attitude in a presidential election and did not cast empty ballot papers, similarly to the repeated parliament attitude of the opposition political representatives of the Sudeten Germans, now substantially strengthened already, i.e. the legislators of their new central opposition and negativistic Henlein's Sudeten German Party (Sudetendeutsche Partei). It is remarkable in this context that it was not Géza Szüllo, the ex-president of the Christian Socialists, the then president of the joint deputy club of both Hungarian parties, but János Esterházy, the OKSzP president, political novice on the Hungarian minority political scene who was invited by Edvard Beneš to negotiations about his support, although Géza Géza Szüllő had stood at the birth of the Hungarian minority political scene in Czechoslovakia and was generationally closer to Beneš than Esterházy, and not a representative of the Hungarian National Party, in spite of the fact that MNP was the closest to the activistic policy in the second half of the 1930s. ${ }^{2}$

In the period of the independent Slovak State, declared on 14 March 1939, Esterházy gained publicity at the $87^{\text {th }}$ meeting of the Slovak Assembly on 15 May 1942 where he was the only one who did not vote for the constitutional law legalizing deportation of Jews that had taken place in Slovakia since the beginning of that year (Act No. 68/1942 on the cancellation of citizenship of evicted Jews). After World War II, he was arrested and hand-

2 For partial topics of Esterházy's role in the Hungarian minority political scene in the First Czechoslovak Republic see several studies by the author of this paper from conferences from recent years: Nástup hraběte Jánose Esterházyho do čela mad'arské Zemské křestansko-socialistické strany v Československu na sklonku roku 1932, in: Moderní dějiny. Časopis pro dějiny 19. a 20. století, 18, 2010, 1, 77-101; Zemská křestáansko-socialistická strana v Československu pod vedením hraběte Jánose Esterházyho v letech 1933-1935, in: Ibidem, 19, 2011, 1, 67-103; Mad'arské menšinové politické strany v Československu a volba Masarykova nástupce do úřadu prezidenta republiky v prosinci 1935, I. a II. díl, in: Ibidem, 20, 2012, 1-2, 157-201 and 83-137. 
ed over to the authorities of the Soviet State Security (NKVD) who dragged him off to the Soviet Union on 29 July 1945, where he was convicted in Moscow to ten years of penal servitude less than one year later, on June 1946, based on trumped-up charges. At the same time, Esterházy was sentenced to death by hanging for high treason, in his absence ("in contumaciam"), by the National Court of Bratislava in Slovakia on 16 September 1947. But after he had been extradited from the Soviet Union, Klement Gottwald, President of the Republic, changed his death penalty, with the assistance of his family and friends, to life imprisonment. Five years later, in 1955, Esterházy's life imprisonment was reduced to 25 years of imprisonment thanks to amnesty. Esterházy died of pulmonary tuberculosis in one of the most cruel prisons for political prisoners of that time on 8 March 1957. The place where the urn with Esterházy's remains had been put was found only fifty years after his death, in 2007.

As Esterházy was a political representative of the minority Hungarians who found it difficult to cope with the creation of the Czechoslovak state, or with the fact that up to seven hundred and fifty thousand of them ${ }^{3}$ had ended up beyond the border of the post-war Hungarian state, respectively, and thus they were perceived in a generalized way as a negativistic and subversive national minority, Esterházy is perceived by Slovak historians as a politician who contributed significantly to the destruction of the First Republic by his opposition and negativistic political attitude towards the constitutional foundations of the Czechoslovak state of that time. On the contrary, the Slovak Hungarian minority, or the Hungarians both in Slovakia and in Hungary, respectively, perceive János Esterházy as a significant political authority of the Hungarian minority, who, from the position of a deeply believing Catholic and Christian-socialist politician, defended the interests of the Hungarian minority in Czechoslovakia based on the principle of peaceful Christian coexistence among individual national groups. Such different views of Esterházy's personality divide the Slovak and Hungarian professional and broader public until today. While the Slovaks perceive Esterházy as a politician collaborating with Horthyan Hungary and as a national traitor who was actively engaged in the destruction of Czechoslovakia, the Hungarians perceive him as a politician - martyr who always acted devotedly in defence of the Hungarian minority in the interests of maximal preservation of its national identity, both in Czechoslovakia, and in the independent Slovak State, resisting, in spite of all pressures, vehemently the transformation of the only allowed party of the Hungarian minority, the Slovak Hungarian Party (Szlovenszkói Magyar Párt), in the spirit of the national-socialist ideology.

Since November 1989, Esterházy's daughter Alice Esterházy-Malfatti (born in 1932, now living in Rome) has been struggling in vain, together with the political representatives of the Hungarian minority in Slovakia, with significant support from the leading political representatives of Hungary, for János Esterházy's rehabilitation and for the invalidation of the decision of the National Court of Bratislava from September 1947. An elementary obstacle to court rehabilitation of János Esterházy consists in the fact that it cannot be initiated based on the provisions of Act No. 119/1990 Coll. on court rehabilitations, as that legal norm of

3 In 1921, 745,431, i.e. 5.6\% inhabitants of the republic claimed allegiance to Hungarian nationality within the first census performed in the Czechoslovak Republic. Similarly to the German minority in the historical countries of the Czechoslovak state, the Hungarian minority constituted the most significant national minority in Slovakia. Compare ČSS - Sčítání lidu 1921, Tab. 50, Národnost československých státních př́ílušníků. I., p. 60*. 
the former Czechoslovak Federative Republic, still valid both in the Czech Republic and in the Slovak Republic, applies only to court decisions delivered in the period from 25 February 1948 to 1 January 1990. An alternative compromise solution of the whole matter, e.g. in the form of a parliamentary resolution, adoption of a so-called Lex Esterházy that would "rehabilitate" from a moral-political perspective the negative consequences of the postwar steps of the Czechoslovak court authorities, steps that had virtually all the attributes of a political process, is out of the question too. Although a means of legal determination how to perceive and interpret some historical events or historical personalities, it is perceived as an everlasting dilemma of history by professional historians. Nevertheless, in 1993, upon the request of Árpád Göncz, the Hungarian President of that time, Esterházy was rehabilitated by the Russian Supreme Court. On the contrary, the Slovak Supreme Court declined to reopen the court process with the former leading political representative of the Czechoslovak Hungarian minority a year later. It is worth mentioning that Slovakia was invited to rehabilitate János Esterházy's personality not only by Hungary. For example in 1999, Alois Mock, the former Austrian foreign minister asked Ján Čarnogurský, the minister of justice of that time to initiate János Esterházy's rehabilitation.

The March international conference on János Esterházy, held in Nitra, his native region, constituted a part of many years' discussion by the Slovak and Hungarian professional public with respect to that national politician of the First Republic. Besides, it was the first conference on János Esterházy hosted by a Slovak state university. That very fact suggests that, in spite of persisting differences among Slovak and Hungarian experts with regard to Esterházy, the common dialogue has had some results in seeking an assessment of his personality and political actions acceptable to both parties. The significance of the international scientific conference on János Esterházy was emphasized also by the active participation of historians from Poland and the Czech Republic; so it can be stated that the Hungarian-Slovakian dialogue on János Esterházy's personality is now becoming a dialogue not only of Slovak-Hungarian historians but also of experts of V4 countries. The broad international dialogue on Esterházy could indisputably be more than beneficial, as it can introduce other aspects into professional discussion, to contribute to a more objective reflection of that Hungarian minority politician from the point of view of the more comprehensive perspective of that time, while respecting the broad context of specific historical-political development of the whole Central European region as viewed by individual nations and states.

The conference was organized by the Living Zobor Region Civil Organization and European Network Remembrance and Solidarity (ENRS) with registered office in Warsaw, under the main auspices of Dr. Csaba Gy. Kiss DSc. From the University of Warsaw as representative of the ENRS. The program of the all-day conference that took place within one plenary session with the broad participation of the audience, including students, was very rich and tight. The conference was opened, on behalf of the organizer, by Zoltán Zilizi, the President of Living Zobor Region Civil Organization, who reminded the audience of the different 
views on János Esterházy by the Hungarian or Polish ${ }^{4}$ and Slovak professional public. He emphasized that the main goal of the conference organizers consisted in trying to contribute to bringing both historical narratives closer together in assessing Esterházy's personality and that the conference forum offered a space to all mutually opposed perspectives under the active participation of leading Hungarian, Slovak, Czech and Polish authorities in that field. Then all attendees were greeted by Attila Komzsík, the Dean of the hosting faculty, and by the conference patrons, the president of the Scientific Council of ENRS, Csaba Gy. Kiss, as well as by the president of the Steering Committee of ERNS, Jan Rydel, by the former president of the Slovak Parliament, František Miloško and by the Hungarian ambassador to Slovakia, Csaba Balogh. Also the speech of Tomasz Chlon, Polish ambassador to Bratislava, delivered out of the actual agenda, deserves attention. The Polish ambassador to Slovakia emphasized the need to discuss even tabooed topics, drawing attention also to the indispensability of a dialogue to understand the other party's arguments. But at the same time, he pointed out that mutual communication of the parties should not be mere deaf dialogue heading from the formulation "my hero, your enemy" to enforcement of the formulation "my hero who must be accepted by you".

After the opening salutatory speeches, the conference continued in three successive blocks, within which the speakers evaluated and highlighted different aspects of János Esterházy's political activity, role and efforts in the context of the history of the First Czechoslovak Republic and the Slovak state.

The first section, lead by the author of this report, included speeches by Arkadiusz Adamczyk from Jan Kochanowski Uniwersity, Branch in Piotrków Trybunalski in Poland, László Szarka from the Research Centre for the Humanities - Institute of History of Hungarian Academy of Sciences in Budapest and Imre Molnár from the Hungarian Ministry of Foreign Affairs in Budapest. Colleague Arkadiusz Adamczyk devoted his lecture to Esterházy's political actions from the Polish point of view, or to contacts between János Esterházy and the Polish Foreign Minister Józef Beck, respectively, within the efforts of the latter, a key political personality of Poland in the 1930s, to achieve understanding among small nations, which constituted virtually a last attempt to reconcile the geopolitical situation in Central-Eastern Europe before World War II.

László Szarka dealt with Esterházy's autonomist policy in the context of the first Vienna arbitration, based on which the Czechoslovakia of that time had to cede a considerable part of the territory of Southern and Eastern Slovakia to Hungary and the Southern-Western part of Carpathian Ruthenia, while those territories had been awarded to the Czechoslovak state by the Peace Treaty of Trianon. Colleague Szarka reminded the audience that Esterházy's autonomist policy aimed at establishing not only Slovak-Hungarian cooperation but, in the longer perspective, naturally also the potential revision of the Trianon borders. He also pointed out the fact that the failure of the autonomist policy caused by the territorial destruction of the Czechoslovak state in 1938 had led to further sharp deepening of the hostility between the Slovaks and the Hungarians whose mutual friendly cooperation had

4 Let's remind here that János Esterházy's mother was the Polish Countess Elżbieta (Erzsébet) Tarnowska (18751956), daughter of Count Stanisław Tarnowski (1837-1917), a Polish literary historian, conservative politician, rector of the Krakow University and president of the Krakow Imperial Academy of Sciences. That is one of the reasons why Esterházy is paid attention also in Poland. 
been Esterházy's continuous goal, as well as the peaceful coexistence of free nations and independent Central European nations. László Szarka evaluated Esterházy as a modern national-minority politician, who had been, of course, also flesh and blood and, as such, had often erred. He also pointed out that Esterházy had got to top politics as a young and inexpert person, in a situation when he, as a national-minority politician, had to learn to consider three capitals, Prague, Budapest and the arising capital of Bratislava, but as he had also strong Polish identity, Warsaw was important to him as well.

Imre Molnár pointed out in his lecture that Esterházy's defence of the interests of the Hungarian minority in Slovakia never had converted him into an enemy of the Slovak nation. The presenter of the section, the author of this report, highlighted that fact as well, pointing out the specific supranational geographic Central European patriotism of representatives of traditional famous aristocratic families including János Esterházy. He restated that when examining János Esterházy's personality, the Central European dimension of his political thinking, rooted in the class perspective of the perception of the "nation" must be perceived within a large and varied multinational Hungarian or Austro-Hungarian state, respectively.

The second block of lectures, led by Tibor Žilka from the hosting faculty, included three speakers too. Ondrej Podolec from the Institute of the Slovak National Memories and the Faculty of Law of Komenský University in Bratislava pointed out at the beginning of his lecture that János Esterházy's issue is situated on the margin of interest of Slovak historiography that, in relation to Esterházy's personality, usually responds to outer impulses only, particularly from the Hungarian side. Podolec summarized in his lecture the main theses of the political actions of János Esterházy from the perspective of official Slovak historiography that perceives him in general as an irredentist and revisionist politician cooperating with the Hungarian government. As Podolec stated, Esterházy had primarily dealt with assertion of the rights of the Hungarian minority, not dealing with the rights of other national minorities. He characterized János Esterházy's political actions in the Slovak State as full of contradiction, calling problematic particularly Esterházy's contradicting attitudes in relation to the anti-Semitic laws of the Slovak State.

Colleague István Janek from the Research Centre for the Humanities - Institute of History of the Hungarian Academy of Science in Budapest devoted his lecture in detail to János Esterházy's mediation activity between the Hungarian and Slovak government in 1939 to 1942 , or to his political actions in the interest of the Hungarian minority in the Slovak state and of the Slovak minority in Hungary, respectively, championing the concession of the status of national minority to the latter in Budapest. The second part of his lecture dealt with the issue of Esterházy's attitude to the Jewish issue, or with the different interpretation of his attitudes in this context, in the fascist Slovak State, by Slovak and Hungarian historians, respectively. Janek concluded his lecture by stating that Esterházy had not been an anti-Semite but he had carried the bias against Jews, typical and common in that time, which must be strictly differed and separated. The second block of lectures was terminated by the lecture of Ján Mitác from the Institute of the Slovak National Memories in Bratislava, evaluating critically the minority policy of Horthyan Hungary as against the Slovak minority in the former South-Slovakian territories annexed to Hungary, in the context of János Esterházy's attitudes, criticizing him for not having condemned in public the national oppression 
of Slovaks in Hungary and the violent excesses against the Slovak population.

The third block of the conference, held in the afternoon and presented by Ondrej Podolec, was opened by the lecture of the author of the report from the conference. He presented János Esterházy based on selected archive sources of the First Czechoslovak Republic preserved in Czech archives, including those coming from the Ministry of the Interior, the Office of the President of the Republic and the National Assembly of that time. Based on them, he primarily tried to point out interesting moments of Esterházy's political activity during the First Republic in the 1930s, particularly with emphasis on his role in the presidential election of December 1935, and interesting moments from his contacts with Edvard Beneš, the second Czechoslovak President.

Another two lectures concerned the period following World War II. Dariusz Rogot from Jan Kochanowski Uniwersity, Branch in Piotrków Trybunalski in Poland presented an interesting lecture mapping the tragic fate of the Eastern and Central European political elite in Soviet labour camps, in the context of Esterházy's forced stay in gulags after having been deported to the Soviet Union and condemned to ten years of forced labour. The last three lectures were concluded by Ferdinand Vrábel from Bratislava, who is one of the few Slovak historians dealing in detail also with János Esterházy's person, as Podolec, the block presenter, pointed out. Colleague Vrábel familiarized the audience with the role of minister Vavro Šrobár in the change of Esterházy's sentence to life imprisonment on the background of two letters: the letter from Esterházy's mother, Elżbieta Esterházy, and the letter from Esterházy's sister, Lujza Esterházy from 1949, addressed directly to Šrobár (who held the position of minister of unifications at that time) and concerning the change of the sentence, or pardoning of János Esterházy; Vrábel had found their originals in the Literary Archive of the Slovak National Library of Martin. Šrobár's role in pardoning of the original death sentence in Esterházy's case was known, but no document evidencing it had been discovered before.

The subsequent discussion at the end of the expert part of the conference included positive reactions to the speech of Imre Lebovits from Budapest who had survived the holocaust and, in September 2011, wrote an open letter to President Ivan Gašparovič, criticizing him sharply for having called Esterházy a supporter of Hitler and fascism in the context of the unveiling of his statue in Košice. Particularly the following Leibovits' words provoked a reaction among the audience: "The look into the face of the past brings drawbacks with it. It should be considered whether Slovakia should not be more benevolent to Esterházy, who was rehabilitated even by the Soviet Union. This is what a Jew tells you."

The conference was concluded by a discussion table in late afternoon, under the participation of Imre Lebovits, Imre Molnár, István Kollai from the Hungarian Institute in Bratislava, Martin Hetényi from Konštantín the Philosopher University in Nitra, Ondrej Podolec, Pál Csáky, a publicist, former double deputy prime minister of the Slovak Republic in 19982006 and former president of the Hungarian minority party in Slovakia, the Party of Hungarian Community (Strana mad'arskej komunity, SMK) in 2007-2010 (in May 2014 elected to the European Parliament on behalf of SMK) and Viliam Jablonický from the Slovak Centre of P.E.N. International.

Within their answers to the questions of Zoltán Zilizi, the discussion presenter, the round table participants completed their views on János Esterházy's personality, or tried to sup- 
port the assessment of János Esterházy's political role with further arguments in the interest of the general attitude to the issue from one or the other block. I would point out the interesting contribution of Pál Csáky, out of the rich discussion. According to the former deputy prime minister of the Slovak government, János Esterházy should have a claim to a dignified court decision. He pointed out that, as deputy prime minister, he had asked Ján Čarnogurský, the Minister of Justice of that time, that the possibility of reopening Esterházy's case in court should be examined. According to Csáky, the Ministry of Justice came to the conclusion that if the issue of Esterházy's personality was examined at court again, he would have to be automatically rehabilitated because the concerned bad law setting norms to work of the popular courts of that time had been violated in three points at the minimum. Nevertheless, in the discussion, Csáky supported unambiguously the need to re-negotiate the court process with János Esterházy with the Supreme Court of the Slovak Republic. He also emphasized the need to move Esterházy's remains from Bohemia to his native region.

The final round table confirmed the continuing different attitudes of the Slovak and Hungarian historians to the assessment of János Esterházy's personality, but the discussion had factual development, although it could be clearly seen that some attitudes to Esterházy were assailed by politically narrow-minded views. But in any case, the round table discussion showed that common dialogue of both parties is the path that, perhaps, could create the necessary platform for such a picture of the politician János Esterházy that would respect the view on that leading personality of the Czechoslovak or Slovak Hungarian minority in the 1930s and 1940s consistently from the perspective of that time. Such dialogue and such attitudes to Esterházy could blunt markedly the sharp contradictions between the Slovak and Hungarian assessment of the political activities of that minority politician. I feel that the current view not only on the issue of János Esterházy's personality as political representative of the second largest national minority in the First Czechoslovak Republic, later as the only representative of the remaining Hungarian national minority in the assembly of the Slovak State, particularly the view of the Slovak historiography, is kept assailed by the modernistic attitude, based more on insufficient statement of bare data from preserved archive documents, viewed from the perspective of present time, a time distant by several decades from the authentic time, when the events and circumstances of the 1920s, 1930s and 1940s are only difficult to interpret objectively through the prism of today. And that applies, in fact, to the whole set of complicated historical-political or social-political-cultural issues of that time, whose main determinant consisted in the nationally very mixed society of the Czechoslovak state and rigid socio-cultural frameworks of behaviour of the society of that time that was kept assailed by the "old" perspective of the world within the limits of the time before 1918. That is logical, as political development is always faster than the society's adaptability to new trends, new orders and the requirements of a new time. And that is what we should consider in our historical research.

The political activities, ideas and legacies of the politicians of the period in question should be perceived fully and strictly within the context of the given time, in the norms of the socio-cultural perspectives of political reality of that time, but above all from the perspective of all parties involved. A fully post-modernistic attitude must be applied here, and the given historical-political events must be examined within its rules, through their individual 
actors, through the socio-cultural perspective of their time, based on deeper socio-cultural traditions that, in addition, often differ diametrically from the socio-cultural traditions of the other party. The modernistic approach, without due contextual interpretation of the data from archive sources, freed from the narrow-minded perspective of one or the other party, can never be considered objective. Only their interpretation through current post-modernist attitudes in historical science, based on the effort to understand common parallels, causes and consequences of the contact and contradictory moments from the perspective of historical-political events of all parties involved can lead to the desired more objective evaluation. And even in such a manner, we certainly will not always achieve an absolutely objective view and interpretation, acceptable to both parties; nevertheless, we can get at least very close to it, as our investigation will be based on the effort towards mutual understanding of the attitudes of individual interpretations in a broader context, thanks to the effort and desire to understand the prism of the period in question and the perspective of its actors. All that can be certainly supported by common factual dialogue that must be based primarily on interpretation in historical context, with understanding of all actors, whose attitudes are either close or distant to us, not only on pointing out bare facts.

Andrej TÓTH

Faculty of Public Policies Silesian University in Opava

Czech Republic 